\title{
POSISI SAINS DALAM PERADABAN SAAT INI
}

\section{Suharto \\ Universitas Negeri Semarang \\ suharto@mail.unnes.ac.id}

Tak bisa dipungkiri bahwa sains maju dengan pesat pada jaman modern. Jaman yang didahului renaissance yang akhirnya muncul jaman positivisme ini menjadi pemicu melesatnya perkembangan sains ini berlipat-lipat lebih cepat dari jaman sebelumnya, jaman pra-modern. Jaman pra-modern walaupun berusia cukup lama tetapi perkembangan peradaban berjalan sangat lambat, kalau tidak dikatakan statis. Pada jaman ini dunia dikekang oleh hegemoni agama dengan dogma-dogmanya yang oleh para filosof di jamannya dianggap sebagai jaman penuh mitos. Hegemoni agama yang juga didukung oleh kekuasaan menambah penderitaan karena 'penindasan' itu. Beruntunglah berkat filosof-filosof alam seperti Socrates, Plato, dan Aristoteles telah membuka tabir kegelapan itu berangsur benderang. Aristoteles misalnya, telah membangun dunia logis, sehingga, Aristoteleslah yang dianggap sebagai Bapak logika yang manjadi cikal bakal lahirnya sains.

Dalam 'pertarungan' antara mitos dan logos saat itu akhirnya logoslah yang menjadi pemenang. Namun demikian, antara mitos dan logos sebenarnya tetap 'hidup'. Mitos yang juga dianggap sebagai embrio filsafat masih tetap eksis dengan dunianya, bahkan sampai saat ini. Sementara logos dengan sains yang dilahirkannya juga berlari dengan cepatnya, jauh meninggalkan dunia mitos.

Pertarungan keduanya yang digambarkan di atas, yang kemudian dikenal dalam sejarah Yunani Kuno dianggap telah memberikan pengaruh besar terhadap lahirnya filsafat ini, logos dianggap sosok 'pahlawan' yang selalu memenangkannya. Kemenangan logos yang ditandai dengan kematian mitos selanjutnya membawa implikasi positif bagi eksistensi dan legistemasi dirinya (logos). Pertarungan yang terus berlangsung ternyata mitos memang tidak benar-benar mati, atau paling tidak telah bermetamorfosis, dan logos tetap menjadi pemenangnya. Logos yang mampu menunjukkan kesaktiannya dengan perkembangannya yang cepat itu, hingga pada akhirnya dikenal dengan rasio manusia.

Kematian antagonis (mitos) berimplikasi positif bagi kehidupan rasio manusia ke alam pikir yang begitu spektakuler. Lebih-lebih, protagonis (logos) dalam sejarah modernitas dewasa ini, muncul sebagai bentuk rasionalisasi bahwa di mana sang protagonis terbungkus dalam baju 
sains, yang kemudian menjadi saintisme. Dan, pertarungan keduanya dan juga metamorphosis mereka, digelar dalam satu arena dan satu ceritera, sejarah rasionalisme.

Dalam sejarahnya filsafat sebagai penemuan Yunani muncul sebagai bukan dalam segala kepunahannya. Para filosof terutama yang pra-Socrates seperti Phytagoras, Parmenides adalah para genius yang memperkenalkan berfikir kritis terhadap mitos ini. Namun mereka tidak seratus persen tidak meninggalkan mitos (Hardiman, 2003: 173).

Perkembangan sains yang mengarah kepada kehidupan manusia pada posisi yang paling tinggi, ternyata rasio manusia menunjukkan dirinya sebagai 'mitos baru'. Akibatnya, muncul sebuah perlawanan terhadap saintisme yang dianggap gagal mewujudkan cita-cita awal dari sains modern, yakni 'janji pencerahan' yang semestinya menggiring kepada kebahagiaan totalitas manusia. Saintisme adalah suatu kepercayaan bahwa sains adalah satu-satunya proses belajar manusia yang paling bernilai karena sifat kegunaan (pragmatis), autoritatif, dan seriusnya (Sorrel Tom dalam Hardiman, 2003: 174).

Kecenderungan inilah dalam kajian mutakhir menjadi perhatian bagi sekian banyak pakar atau ilmuan, yang masing-masing terlibat secara langsung atau tidak, dalam rangka memberikan respons dan tanggapan positif terhadap masa depan ilmu pengetahuan dan teknologi. Sebab pada kenyataannya, saintisme tidak hanya dianggap telah melahirkan basis pengetahuan yang semu dan nihil, tetapi juga harus bertanggung jawab atas segala kerusakan yang telah dihasilkan selama perkembangan itu.

Sain telah mereduksi, menyederhanakan atau menciutkannya ke dalam kepentingan pragmatis alias kepentingan untuk menggunakan dan manfaatnya (Sugiharto, 2012). Berbagai kasus dan fenomena kehancuran pada dekade terakhir ini merupakan salah satu akibat dari terbentuknya "mitos baru" tersebut di mana sains diletakkan pada posisi yang tidak terbatas, bahkan sains dengan sendirinya telah menggantikan peran-peran yang disakralkan selama ini, yakni 'Tuhan'. Sains maju pesat tetapi dunia agama menjadi tersingkir. Cara berpikir pragmatis ini telah menggelapkan mata yang menurut Heidegger (dalam Sugiharto, 2012) telah menantang (challenging) mengerangkeng (enframing) dan membedah-mengeksploitasi (revealing, exposing). Sain dan teknologi menantang dan menaklukan alam, menghitung dan menggunakan segala yang ditemukan dalam pengalaman. Akhirnya, alam itu pun tidak lagi sesuatu yang harus dinikmati keindahannya, pesonanya, makna hakikinya tetapi sesuatu yang harus dicari 
manfaatnya bagi manusia yang tidak lebih dari benda mati yang memang diciptakan untuk dieskploitasi.

Lahirnya bentuk-bentuk ideologi lain dapat mengarahkan kepada jurang kehancuran masa depan manusia. Kerusakan ekologi adalah akibat dari watak sains yang pragmatis yang melihat lingkungan itu dari jauh, tak melihat lebih dekat tentang hakikat alam seperti oleh seni, misalnya. Sebuah hegemoni liberal yang notabene telah menguasai dunia saat ini telah merambah ke seluruh dunia dengan menyebarkan 'angin surga'. Sebuah contoh nyata adalah eskploitasi alam oleh kaum liberal dan paham liberalismenya yang dengan mudahnya membuat bopeng-bopeng di Bumi Cendrawasih. Iming-iming keuntungan yang didapatkan tidak sebanding dengan kerusakan dan penderitaan yang diakibatkannya. Kemajuan dan keahlian sains yang dimiliki sang pemilik ideologi asing ini telah membius dengan senjata 'rasionalitasnya' mampu membius bangsa Indonesia yang telah memiliki ideologi sendiri yang membumi dan terlena melupakan dan melanggar ideologinya sendiri. Akibatnya, kehancuranlah yang bisa kita dapatkan di masa-masa mendatang jika tidak tersadar dari 'hipnotis' kaum kapitalis yang liberalisme ini. Itu hanya salah satu contoh yang terjadi pada kita.

Watak sains yang lugas, apa adanya dan rasional ini, diakui tidak sedikit telah melahirkan krisis nilai-nilai kemanusiaan. Lagi-lagi Sang Adidaya, yang dengan keadidayaannya dan berkat penguasaan sains dan teknologinya walaupun hasil dari memperdaya negara lain, dengan sengaja menciptakan 'horor' di masyarakat dunia. Dengan dalih kebebasan, HAM, demokrasi, ia menciptakan dirinya sebagai 'polisi dunia'. Lalu dengan 'kewenangannya' melakukan 'operasi-operasi' kepolisiannya di seluruh dunia. Akibatnya, dengan standar ganda politiknya ia menyebar ancaman sampai pada kegiatan represif kepada negara yang inferior. Hasilnya, ujung-ujungnya adalah penerapan paham pragmatisnya dan dengan 'segala cara' mengusai politik dan ekonomi negara yang menjadi targetnya. Jika demikian, maka rusaklah tatanan dunia sekaligus peradabannya. Contoh nyata dari hal ini adalah kerusakan peradaban dunia di Irak setelah Amerika menginvasinya. Peradaban Islam baik berupa simbol-simbol kebesaran bangsa Irak hancur karenanya. Maka, pertanyaan mendasar yang perlu dikemukakan adalah apakah hakikat dan kemanfaatan sains bagi kelangsungan hidup manusia?

Perlu untuk meninjau ulang tentang eksistensi sains, yang pada gilirannya diharapkan dapat memberikan sumbangsih bagi peradaban post-modernisme. Untuk itu, upaya yang sangat diperlukan adalah perenungan kembali tentang hakikat sains secara mendalam guna memperoleh 
suatu jawaban kebenaran hakiki dibalik sebuah sains tersebut. Mendalam tidak hanya terpusat pada hakikatnya, tetapi juga mempertimbangkan masa depan sains bagi kelangsungan hidup manusia. Lebih-lebih memasuki era post-modernisme saat ini, bahwa kecenderungan kehidupan sangat ditentukan oleh sains. Post-modernisme sekarang, bukan hanya menjadi sebuah wacana, namun sudah menjadi kenyataan yang benar-benar terjadi. Kenyataan tersebut ditandai dengan banyaknya manusia telah kehilangan hakikat hidup sebenarnya. Bahkan kehidupan yang mereka geluti di mana pun ia berada, berubah menjadi sebuah bentuk ancaman bukan keselamatan, kecemasan bukan kedamaian. Perlu juga ditinjau ulang 'epistemologi' sains agar 'lebih manusiawi'. Perlu paradigma baru yang bisa memperbaiki watak sains yang tidak semata-mata melihat dari sisi pola-pola abstrak dan objectif sehingga tidak 'mau tahu' sehingga dunia tidak bisa hanya dilihat secara linier tetapi multi arah yang banyak tafsir dan persepsi.

Pengetahuan manusia yang didasarkan pada sains selalu membenarkan sesuatu dari kacamata sains pula. Rasionalisasi dipakai pembenaran untuk menentukan segala-galanya, dan bukan lagi menyertakan nilai-nilai intrinsik yang bercermin pada diri manusia. Karena itu, rasionalitas perlu dicurigai sebagai unsur yang memainkan kekuasaannya. Foucault misalnya, telah membahas persoalan ini secara mendalam. Dari hasil temuanya, dinyatakan bahwa pengetahuan manusia secara tidak sadar ada kekuasaan. Hal serupa juga dicetuskan oleh Sigmund Freud yang dikenal dengan sebutan pikoanalisa. Freud mengembangkan konsep strukture mind dengan mengembangkan 'mind apparatus', yaitu yang dikenal dengan struktur kepribadian Freud dan menjadi konstruknya yang terpenting, yaitu id, ego dan super ego. Id adalah struktur paling mendasar dari kepribadian, seluruhnya tidak disadari dan bekerja menurut prinsip kesenangan, tujuannya pemenuhan kepuasan yang segera. Ego berkembang dari id, struktur kepribadian yang mengontrol kesadaran dan mengambil keputusan atas perilaku manusia. Superego, berkembang dari ego saat manusia mengerti nilai baik buruk dan moral. Ego selalu menghadapi ketegangan antara tuntutan id dan superego. Apabila tuntutan ini tidak berhasil diatasi dengan baik, maka ego terancam dan munculah kecemasan (anxiety). Dalam rangka menyelamatkan diri dari ancaman, ego melakukan reaksi defensif/pertahanan diri. Hal ini dikenal sebagai defense mecahnism yang jenisnya bisa bermacam-macam (Sandra, 2012).

Sains yang menggunakan logika nalar yang awalnya disistematikan oleh Aristotels ribuan tahun lalu ke dalam bentuk silogisme dimainkan melalui konsep-konsep verbal linear (harfiah). Logika ini kemudian dipercanggih sains dan teknologi melaui simbol matematika (Sugiarto, 
2012). Hal ini menjadikan sain berjalan dengan kacamata kuda yang terus lineaer dan tak memiliki rasa dan humanis. Jika kebenaran hanya disandarkan pada kebenaran rasio, maka sangat mungkin untuk dilakukan sebuah "dekonstruksi”. Seperti yang pernah diungkapkan oleh Jaques Derida jauh hari, bahwa dekonstruksi adalah pembongkaran cara berpikir yang kita anggap benar karena rasional. Membongkar di sini dimaksudkan untuk mengembalikan pemikiran itu pada bentuk kesadaran. Sekali lagi, bahwa dekonstruksi merupakan salah satu penyadaran logis apa yang selama ini dianggap dominan, yang justru bertolak belakang dengan janji-janji manisnya, bahkan tidak membahagiakan dan memberi kepastian hidup manusia. Dengan demikian, kalau membongkar pemikiran-pemikiran yang dominan, maka sperlu mendengar semua pemikiran yang selama ini dianggap marginal, tidak logis, atau tidak saintifik.

Sains dan peradaban post-modernisme adalah realitas yang sama-sama nyata. Karena itu, persoalan yang diakibatkan sains dalam post-modernisme semakin hari semakin kompleks. Maka di sinilah perlunya epistemologi dan sekaligus axiologi untuk menelusuri dinding-dinding realitas tersebut. Akan terus terjadi kecemasan jika dalam tataran axiologisnya sains tidak menunjukkan kemanfaatan bagi manusia. Oleh karena itu perlu dicari keseimbangan.

Nilai moral yang harus menjadi spirit dan sumber aktivitas manusia, janagan sampai lenyap akibat tereduksi oleh sains. Secara moral, perkembangan sains harus tetap memiliki tujuan dan cita-cita hidup manusia, dan bukan menjadi perusak. Perkembangan sains tiak bisa kita putar balik ke belakang tetapi biarlah tetap berjalan dengan segala resikonya. Yang perlu diperbaiki adalah penanaman nilai agar terjaga keseimbangan agar sains yang akan terus berkembang ini dapat memberikan manfaat dan tidak mengancam peradaban manusia.

\section{Reference}

Hardiman, F. Budi. 2003. Melampaui Positivisme dan Modernitas. Yogyakarta: Kanisius. Sugiharto, Ignatius Bambang. 2012. Seni dan Dunia Manusia.

Susanti, S. (2011). FILSAFAT SENI: ANTARA PERTANYAAN DAN TANTANGAN (Philosophy of Art : Between Question and Challenge). Harmonia: Journal Of Arts Research And Education, 1(2). doi:http://dx.doi.org/10.15294/harmonia.v1i2.840 
Sunarto. (2011). TUGAS ILMU PENGETAHUAN DAN SENI DALAM ERA INFORMASI

(The Duties of Science and Art in the Information era). Harmonia: Journal Of Arts Research And Education, 2(3). doi:http://dx.doi.org/10.15294/harmonia.v2i3.856

Sunarto. (2013). KESADARAN ESTETIS MENURUT HANS-GEORG GADAMER (19902002). Harmonia: Journal Of Arts Research And Education, 11(2). doi:http://dx.doi.org/10.15294/harmonia.v11i2.2212

Suharto. (2011). Refleksi Teori Kritik Seni Holistik : sebuah Pendekatan Alternatif dalam Penelitian Kualitatif bagi Mahasiswa Seni (Reflection on Art Criticism and Holistic Art Criticism : an Alternative Approach of Qualitative Research for Art Students). Harmonia: Journal Of Arts Research And Education, 8(1). doi:http://dx.doi.org/10.15294/harmonia.v8i1.803

Suharto.(2013). Hari Musik Nasional, Lalu? Gagasan, Universitas Negeri Semarang, 13

Zaenuri, A. (2011). Estetika Ketidaksadaran: Konsep Seni menurut Psikoanalisis Sigmund Freud (1856-1939) (Aesthetics of Unconsciousness: Art Concept according Sigmund Freud Psychoanalysis). Harmonia: Journal Of Arts Research And Education, 6(3).

doi:http://dx.doi.org/10.15294/harmonia.v6i3.811

Malarsih, -. (2011). Seni Postmodern dalam Wujud Konkretnya (Postmodern Art in a Concrete Form). Harmonia: Journal Of Arts Research And Education, 6(3). doi:http://dx.doi.org/10.15294/harmonia.v6i3.815 